discussed subject and websites of the institutions used.

The publication is written in a correct style and understandable, scientific language. It has many new, cognitive values especially in reference to setting up the EDC and tasks that it was supposed to fulfill in the grounds of the treaty of May 27, 1952. The issues concerning political, treaty, operational military (including the ones connected with combat groups) as- pects, aspects of the development of the EU'S defence industry and munitions cooperation that have been presented in various cohesive publications and scientific articles, were blended and developed with new aspects.

It should become an inspiration for other researchers taking up the European Safety and Defence Policy for deepening the problems presented in K.J. Helnarska's book.

\title{
Book review: Sebastian Żukowski, Cosmopolitism And Postmodernism Versus The World Order, „Żurawia Papers”, vol. 13, Institute of International Relations, University of Warsaw, Warsaw 2009, pp. 149
}

\section{by Marcin Chetminiak}

The beginning of the 21st century was a period in which the international order was still in the phase of transformation. The bipolar system, which fell into disintegration along with the end of the Cold War, did not trigger the end of history as some had expected. The international community faced new challenges which will probably require new, more effective instruments. The new conditions of the evolution of the international order pose difficult questions to be answered by analysts of international relations. The ques- tions relate to the analysis of the present order as well as the directions of its short, middle - and long-term development. The international order, as with most of the elements in the theory of international relations, may be analysed from the perspective of various research schools. In Polish literature on the subject it has been viewed mainly from the angle of the classical paradigms: realistic, liberal or normative. Some analysts have also researched the order of international relations from the perspective of transformations in civi- 
lisation and globalization. To date, Polish literature has paid only marginal attention to the analysis of international relations from the perspective of postmodernism and cosmopolitism. It is this subject that is addressed by the book by Sebastian Żukowski, entitled Cosmopolitism And Postmodernism Versus The World Order, published in 2009 as another volume in the "Żurawia Papers" series. The author, a doctoral student at Adam Mickiewicz University in Poznan who also published a book the previous year on the concept of eternal peace in the thought of Immanuel Kant, this time took on the important subject of transformations in the global order and attempted to connect it with the postmodernist and cosmopolitan paradigm.

The book is organised by subject and is clearly and logically divided into three chapters:

1. Cosmopolitism,

2. Postmodernism,

3. Cosmopolitism as a normative narration in postmodernism - the intricacies of the future world order.

In Chapter One, the author analyses the basic theory of cosmopolitism and states that the idea of cosmopolitism may be expressed in three key postulates: focusing on man, versatility and universality. He emphasises that the researchers connected with this theory deal with cosmopolitan democracy and analyse the stability of each democratic system by the extent of personal freedom allowed by each specific system. The conditions that may favour the creation of a global cosmopolitan democracy include, among others, the process of globalization, which does not need to oppose cultural diversity, because the global interdependences build dense intercultural networks. S. Żukowski also criticises the cosmopolitan approach, especially from the perspective of communitarianism, which emphasises the significance of such values as sovereignty and the autonomy of the state. Communitarians also indicate that human rights are part of the jurisdiction of the state.

Chapter Two presents the major assumptions of postmodernist theory. The author writes that postmodernism criticises the faith in the human reason as an objective and rational source of cognition and knowledge. According to postmodernists, in reality the social world does not exist and the perception of social reality is determined by texts on its subject and the scientific interpretation of empirical research. The basic method of studying international relations as used by postmodernists is the method of deconstruction and the history of contemporary times (genealogy), i.e. such historical thinking that reveals and indicates the significance of the relations between power and knowledge. 
The final part of the work examines, among others, the normative premises of the cosmopolitan world order emerging among the intensification of globalisation. It also points out that the cosmopolitan project "requires the institution of a new level of democracy, an anti-national sentiment, listening to the voices of multiple communities, acceptance of the ambivalence inside one's own society and breaking technocratic assurances provided by experts. (...) The key question is providing citizens with new possibilities for dialogue or adequate forms of education, as may be desired in this context". In view of the considerations of the new world order, the book poses the problem of reform of the United Nations and the concept of global governance, which involves a more or less formalised system of making and implementing decisions by the actors of global cooperation. These include not only state actors and the institutions created by them, but also the equally important nongovernmental participants. This type of international governance assumes the appointment of certain structures (functioning permanently or $a d h o c$ ), which would act on various levels and in various spheres of cooperation ${ }^{1}$. The author points out that this type of governance may be instrumental in tackling - called wild capitalism.

1 B. Hettne, In Search of World Order, [in:] B. Hettne, B. Odén (eds.), Global Governance in the 21st Century: Alternative Perspectives on World Order, Stockholm 2002, pp. 6-7.
Sebastian Żukowski is undoubtedly right claiming that "the international order based on the national state has numerous drawbacks". He believes that an alternative to solving many international problems may be combining the cosmopolitan and postmodernist approaches. However, the work under review does not provide the reader with easy solutions, because such may not exist. Certain ideas presented by the author seem to be rather unrealistic. For instance, he proposes the reform of the United Nations by forming another general assembly that would be civic in character, elected in general elections and incorporated in the UN system. The task of the Global Peoples Assembly would be to create universal standards related to the reinforcement of peace, as well as supporting development and social justice. This is certainly an interesting idea, but it is more of a conceptual experiment than a real alternative, at least in the short - and middle-term perspective. Appointing such a body would require the consent of UN member states to change the United Nations Charter, which is at present unimaginable. It would be even more problematic to conduct such common and truly free elections in undemocratic countries or in countries where democracy is not yet consolidated. Moreover, the author himself presents the results of the Fourth Wave Word Values Survey conducted in 70 countries, which indicate that only $7.8 \%$ of people identify themselves as being "citizens of 
the world." S. Żukowski, refers to Jürgen Habermas and rightfully analyses the interactions between the global and regional order without overestimating the extent to which the global order affects the regional order and vice versa. The author concludes the book somewhat prophetically claiming that "a revolutionary overturn of the national state order is the only feasible in the form of a cosmopolitan establishment, which would regulate itself in the form of a political, pragmatic and ethical prophecy."

The main advantage of the book under review lies in its innovative approach to the global international order. The Polish literature dealing with the theory of international relations so far has not had such a detailed analysis of this issue from the perspective of postmodernism and cosmopolitism. It should be emphasised that Sebastian Żukowski based his book on a wealth of literature, predominantly in the English language. Even if certain theses may seem controversial, and some of the postulates are bordering on "wishful thinking", they are still worthwhile. Apparently, this type of analysis of international reality, remaining in the opposition to the classic paradigms of realism and liberalism, will definitely become more and more popular in the Polish studies of international relations. In places, the book is written in a hermetic jargon, which may to some readers prove difficult. This is because the author - as he admits in the introduction - conducts his analysis using the research categories and instruments typical of postmodernism. Nonetheless, this undoubtedly interesting book leaves the reader somewhat unsatisfied, as it lacks, among others, an accurate definition of the world order itself. The author openly expresses his sympathy for the postmodernist approach and, obviously, pays more attention to the deconstruction of the existing concepts. Still, it would be useful to attempt a more precise definition of the world order, all the more because it is the key concept for the entire academic reasoning presented in the book. All we can read in the introduction is that the author uses the concept of the world order instead the international order because " $(. .$.$) this$ enables a wider and more eclectic definition of the research area in the context of the contemporary times undergoing globalisation". Further chapters indicate that S. Żukowski understands the concept not only in its political, but also social, economic and cultural sense.

The work under review is worth recommending to anyone interested in theories of international relations. It should be of particular use to academics, students and experts who wish to analyse international relations from the perspective of postmodernism and cosmopolitism. 